Journal of Humanities, Social and Management Sciences (JHSMS)

eISSN: 2788-4791 (online)

https://doi.org/10.47264/idea.jhsms/2.2.4

Vol. 2, No. 2 (July-December 2021), 42-54

https://www.ideapublishers.org/index.php/jhsms

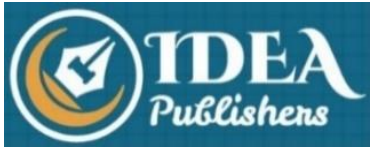

Research Article

\title{
The emergence of Gandhara Civilization: A politico-historical discourse
}

\author{
Nadim Ahmad* | Aziz Ur Rehman \\ Department of Political Science, Qurtaba University of Science and Information Technology, Peshawar, \\ Pakistan. \\ *Corresponding Author Email: ndm.ahmad789@gmail.com
}

Received: September 4, 2020

Published: September 17, 2021

\begin{abstract}
This paper aims at to investigate the ancient regional political history (600-180 BCE), which seems the foundation of Gandhara Civilization that emerged in the Northwest of the Indian subcontinent. The evolution of Gandhara Civilization and emergence of ancient regional political history deem consolidated. In this paper, it would be endeavoured to address the emergence of ancient regional political history that paved the way for a great civilization. The employed design to address the question is historical and qualitative. For the collection and analysis of the data, the qualitative historical approach is adopted. The edifice of present work is mainly erected on the archival sources, reputed journals, historical literature and version of prominent scholars associated to the field. Gandhara possessed a decent political exposition during its early phase. It remained an empire during Pakosati, a federating unit during Persian, independent kingdoms during the invasion of Alexander and remained central part of Mauryan Empire. The emergence of Gandhara is the exposition of politico-historical discourse of the region, which is the foundation of Gandhara Civilization.
\end{abstract}

Keywords: Mauryan region, Ancient history, Empire, Persians, Cyrus, Greeks, Alexander, Gandhara, Monarchy, Kingdoms.

How to Cite:

Ahmad, N., \& Rehman, A. U. (2021). The emergence of Gandhara Civilization: A politico-historical discourse. Journal of Humanities, Social and Management Sciences (JHSMS), 2(2), 42-54. https://doi.org/10.47264/idea.jhsms/2.2.4

Publisher's Note:

IDEA PUBLISHERS (IDEA Journals Group) stands neutral regarding jurisdictional claims in the published maps and institutional affiliations.

\section{Copyright:}

(c) 2021 The Author(s), published by IDEA PUBLISHERS (IDEA Journals Group).

\section{Licensing:}

This is an Open Access article published under the Creative Commons Attribution-NonCommercial 4.0 International License (http://creativecommons.org/licenses/by-nc/4.0/) 


\section{Introduction}

Gandhara was a stable empire (Mahajanpada) that emerged by 600 BCE in the region. It persisted a political unit of Achaemenids in 550 BCE. Persians followed by Alexander in Gandhara by 326 BCE that contributed enormously to the regional political history. Mauryan depleted the region from Greeks and established a great empire (305-180 BCE) in the region. The ancient past of the world is the story of civilization, which refers to the advancement of human society that emerged in particular age and region. The ancient Egypt, Indus valley, Persia and Greek had been passed the great civilizations of the world. Gandhara (600 BCE to $1100 \mathrm{CE}$ ) was one among those great civilization that had significant contribution of multidimensional nature belonging to the region and its people hence the political history of Gandhara (600-180 BCE) is considered the magnificent part and the foundation of Gandhara Civilization.

The emergence of Gandhara is subjected to the political history (600-180 BCE) which could be declared a great and dynamic period of the region. Gandhara emerged a stable empire during the reign of Pakosati (the first emperor). The expansion of Persians, Invasion of Alexander and the establishment of Mauryan Empire were the great events on the part of regional political history. Gandhara civilization had been existed a great civilization in ancient times in the Northwest of the Indian Subcontinent. The early centuries of Gandhara Civilization constituted the splendid political history. It was the prodigious period of Gandhara Civilization that patchworked different civilizations in Gandhara.

Different endeavors had been carried out to grasp the very question of Gandhara Civilization. The history, religions, archaeology, culture and languages are investigated in the previous studies, however the political history of the region having thirst and quest for research that how the regional political history contributed to the foundation of Gandhara Civilization. The selected literature describes the subject in different connotation and context. Khan (2014) investigates the remnants and cultural hermitage of Gandhara, Quraishi (1974) discovers the region the legacy of Indus Civilization. Burq (2008) and Spain (1963) explore the regional history of the people. Dani (2007) portrays Gandhara from the viewpoint of archaeology. Chiragh (2001) compiles the regional history from the Stone Age by approaching the recent past. The multidisciplinary work of Herodotus (2005) provides a general insight into the ancient past of the region by recording the Greeks' struggle and freedom against the Persian hegemony. Rashid (1992) focuses on the legacy of Gandhara Civilization its political magnitude from Alexander until its decline. Amjad (1999), Avari (2007), Harman (2002), Mahajan (2016), Robb (2002) and Nehru (2004) encompass the ancient history of the region. Chamoux (2002), Durant (2000), Higham (2008), Bogoucki (2008) and Iqbal (2002) investigate the subject of civilization and Gandhara the two separate entities.

Gandhara Civilization had multidimensional aspect associated to the history, religions, culture and archaeological study of the region. However, the political history of the region is of paramount importance that is not weighed accordingly. The present work includes the emergence of the political history of Gandhara Civilization from the period of Pakosati till the decline of Mauryan Empire.

The paper is divided into five parts, the first section discusses the applied method along with the used material for analysis and discussion. Section 2 describes the making up of Gandhara 
Civilization by conceptualizing its political history. Section 3 elaborates the expansion of Achaemenids and inclusion of Gandhara in their empire. Section 4 covers the invasion of Alexander and its implications on the regional history. Section 5 includes the foundation and decline of Mauryan Empire being a splendid period of regional political history. The last section 6 concludes the overall findings of the research study.

\section{Research methodology}

The Underlying study is qualitative having historical nature of research while the material and sources are secondary to a great extent. The events and historical facts of the past have been interpreted and explained that associated to the early period of Gandhara to present a compact view of the political history of the region. Being a historical research, the qualitative technique is applied for the collection and the interpretation of data. The consulted sources are archival documents, books, journal articles and encyclopedia articles produced in the field of history, archaeology, culture and religious study of the region.

By consulting the past, neither the political development is static nor is the political evolution over. The origin of the state embedded in the political thoughts and philosophy being formed and developed in ancient times that refer to the affinity of political development and evolution. Political evolution involves the invention, elaboration and diffusion of novel political forms of all types and only some may be more effective, or inclusive, or democratic (Corning et al., 1988). Besides that political development is situation specific while political evolution is historical that consist of gradual transformation. The political development in ancient times in the region reflects the sophistication of Gandhara region while it's dynamic nature from the emergence refers to the political evolution. Hence, the theory of political development and political evolution have been applied for the better understanding for the emergence of Gandhara civilization being a politicohistorical discourse.

The obstacle in conducting the present work is the confusion regarding the concept of Gandhara as well as the conceptualization of term civilization. Not only in general public but academia having discombobulation that civilization is the not the domain of political study but consider it the part of archaeological discipline. The amalgamation of Indus and Gandhara, Buddhism and Gandhara, culture and civilization are hindrance which have created impediments for the smooth-textured understanding of Gandhara Civilization in general while its political history in particular.

\section{Backdrop of Gandhara Civilization}

Gandhara had been passed a great civilization thrived in the region that had multifarious contributions associated to the past of the region and its people. Gandhara Civilization existed from the middle of the 1 st millennium BCE to the beginning of the $2^{\text {nd }}$ millennium CE. Although multiple major power ruled the region in its early period. It remained a great period of cultural, religious and political development that formed a decent legacy with unparalleled influence on the regional political history. The religion, culture, archaeology, art, artifacts, language and education system of Gandhara are of paramount importance hence the political history refer to the tremendous contribution and legacy of its great civilization. Gandhara existed in the Northwest of Indian subcontinent present day khyber Puhktunkhawa, Taxila 
region, Jehlum, Sialkot in Punjab and Eastern part of Afghanistan including Kashmir on the part of greater Gandhara.

The evolution and history of human civilization comprised on several thousand years by approaching to the advanced age at present. The past of the world witnessed the great civilizations as Mesopotamia (3500-500 BCE), Indus Valley (3300-1700 BCE) ancient Egypt, (3100-2486 BCE), Chinese Civilization (1600-1046 BCE), Roman Civilization (550-465 BCE) and Persian Civilization (550-330 BCE) etc. (Andikari, 2019). Notwithstanding Gandhara Civilization (600 BCE to $1100 \mathrm{AD}$ ) persisted one of the great civilizations. It has sound exposition in the religious and sacred literature of the region (Naveed, 2015). The emergence of Gandhara Civilization refers to the foundation of stable empire of Pakosati in the beginning of $600 \mathrm{BCE}$. The Persian expansion took place by capturing the Pakosati empire in the region. Achaemenids lasted till the invasion of Alexander in Gandhara. Alexander returned soon to Greek but left great implications on the part of Hellenic civilization. Mauryan depleted Gandhara from the Greek and succeeded in the establishment of a great empire in the region called Mauryan Empire. Though the region had decent past as, Chiragh (2001) views the distinct identity of the people of Gandhara dates back to early Stone Age.

Different theories had been prevailed and existed to conceptualize the subject of Gandhara. It might have several meanings as well being taken in the different connotation and context. The most prominent among these in etymological context is the Sanskrit origin of the term Gandhara. As it is developed from Qand or Gand means 'fragrance' while 'Har' stands for land, means the land of fragrance (Naveed, 2015). Besides that in the geographical context, it is considered Qand or Gand formed from 'Kun' the 'well' or 'pool of water', as Gand-ao or Gand-ab (Water Lake) and Gand-Dheri (water hill or mound). Others consider Gandhara the old name of Peshawar Valley, bordered in the East and West by Indus River and Sulaiman Mountains (Khan, 2014). The new term, as khan conceives, coined and identified is the Greater Gandhara that was comprised of the valleys of Eastern Afghanistan, Swat Valley, Bannu, and the Taxila Valley. Spain, (1963) argues that the word Gandhara had roots in history, 'Gandharoi' or 'Gandharue' that known to the prominent historians, Herodotus, Ptolemy, and Strabo, while Gandhara appeared around 6th Century BCE.

Herodotus conceives that Gandhara is taken from Gandharioi the tribe living in the region between India and Persian before the subjugation of the region by Achaemenids (Khaw, 2016). Though, historically Gandhara is illustrated in the sacred books of Rig Vida (1800-1000 BCE), Athra Veda (1000 BCE to 800 BCE) and in Ramayana (5th to 4th BCE) in different connections with the region (Khan, 2016). Hiuen Tsang (602-664 AD) views Gandhara region from Kunar (Afghanistan) to the Indus River (region watered by Swat and Kabul rivers). According to the author Gandhara region covered the North to South $370 \mathrm{~km}$ while East to West $296 \mathrm{~km}$ respectively. So for as the cultural frontiers and boundaries identified in the archaeological excavations as sculpture and monument, that stretches from Taxila, Margala Pass, Eastward to Maikyal Indus, Kabul including Bamyan valley located in the western part of Gandhara while Hazara and Swat to North and Soluaiman mountains located in the South. Gandhara Civilization is a comprehensive word due to its multidimensional structure and different connotations. It seems a great civilization that had multifaceted nature rooted in the regional political history. The political history of Gandhara started by $600 \mathrm{BCE}$, peaked from 1st Century $\mathrm{CE}$ to 5th Century CE, and ultimately perished in entirety in $1100 \mathrm{CE}$ (Naveed, 2015). 
However, the emergence of Gandhara comprised on the period from its first emperor Pakosati by approaching to the establishment of Mauryan Empire in the region.

In geo-political context Persians considered, the plain of Indus their frontiers, on other hand Indians claimed Afghanistan as an important region for their activities (Avari, 2007). However, the central India (now) had just three regions; the Gangetic Basin had eleven others while two regions were existed in the Northwest of Indian subcontinent. According to Chiragh (2001) by 1200 or $1300 \mathrm{BCE}$ the rulers and heads (Rajas) of the concerned regions fought against each other. In political context by $8^{\text {th }}$ BCE the Janapada kingdoms and autonomous regions are explicitly visible as Panini had been recorded the sixteen regions (Avari, 2007). The ancient past remained dynamic in the context of Power politics which continued throughout the past both in the term of sustaining peace as well as for the provoking of war. According to Olmstead (1948) in 547 BCE Persia and Greek (the superpowers and great civilizations) signed a treaty that created hope for Greeks to get economic and political advantages. Besides that, the neighboring city-states might submit to their allegiance, earlier Persian had dominated the international relation as compared to Greek and had influential role inside the Greek. Persians expansion and Greeks arrival to Gandhara and the establishment of Mauryan empire is preponderant for understanding the regional politico-historical discourse.

The political system developed with the passage of time both in the term of theory and practice, which included on the journey of several centuries by approaching to the modern sophisticated system of government. In the modern concept of democracy power is vested in the people while the ancient structure of the region the unit of power was family, several families lived in villages (grama) headed by an elder one, which resulted in clan ownership of villages and consequently a clan formed a community (Avari, 2007). The authority and the community structure as well the concept of state subsisted in the early Vedic period. Instead of king, clan chieftains were dominant. The established structure of communities developed and became a part of the region or states the Jananpada. Avari, believes, that the ideology that the kingship evolved from the chieftain of the clan gradually to the assemblies which controlled the exercise of the king (Raja). Consequently, the authority of king decreased from such assemblies.

The literary work on political system is the great asset in this regard. Though Aristotle (384$322 \mathrm{BCE}$ ) is considered the father of political science who believed politics a power full branch of science. In this regard the ancient literature on the political structure of the ancient Indian subcontinent reflects the different perspectives of the political system of the region. Dr. Altikar declares, Arthasastraas a guide focusing on the theoretical orientation of polity which tackles the philosophical foundation and principle of political science (Mahajan, 2016). Megasthenes, work Indica (302-298 BCE) discusses the different aspects of the life of the Indian subcontinent; he served as ambassador of the Seleucus Nector in India (Avari, 2007). Panini and Kotlya contributed enormously in the term of literature that produced in the region.

During the passage of time the monarchies superseded by the republican system due to regional autonomy (Mahajan, 2016). Hence, two aspects seem common as Avari, (2007) understands: the first one was the corporate system of government, in which the senior of the family joined the convention in the central town while leaders were respected, regardless of the hereditary system. The second lineament was the extreme hostility of Brahmin supremacy and cast system based on the Vedic tradition of citizenship devised as class division. Although, in contrast, according to him the clan states were small in size as well large kingdom were also existed 
which ruled by Monarch or the political system there was monarchy. The Empire was comprised of the central state that controls a diverse population as well as a vast territory. Although all the empires of ancient times did not grow and peaked in the same way in history. The Persian empires grew in 30 years and met its climax in 75 years. On the other hand, the Roman Republic emerged in the sixth century while reached its zenith in 117 Century AD (Avari, 2007). The clan system proclaimed by historians were Oligarchies, republican as well as democracies. According to Mahajan (2016), the nature of state was more republican rather than a monarchy. The monarchy then succeeded by the republican system in the period of Buddha which spread in the Gandhara kingdom as well outside of its border. Avari (2007) argues, that the clan states were governed by oligarchy while the kinship was replaced by the republican set up.

The role of religion in the political system having debatable nature. In Gandhara religion vividly occurred in the political system that predominately played a due role in Indian polity. The caste had the established system for the persistence of balance of hierarchy. On the part of evolution the regional history is divided into four major eras i.e. Paleolithic age, the Vedic Period (3000 BCE to $2000 \mathrm{BCE}$ ), the emergence of Great empires (300 BCE to $500 \mathrm{CE}$ ), and the Feudal era (500-1200 CE) (Avari, 2007). Gandhara came under the subordination of various dynasties and empires that ruled the region. The emergence of Gandhara witnessed the great civilizations of the world of that time. The emergence refers to the dynamic period of Gandhara being the early phase of it. As after 600 BCE, two major developments occurred in Gandhara, firstly, the complex state system, and aftermath the clan states instead of petty polities structure (Avari, 2007). The clan state existed in Himalayan foothills, northwest of the Indian subcontinent, borders of the central kingdom in the Sindh, Punjab, and central parts of India. People of clan states had been accustomed the democratic rights, as participation in the assemblies and enjoyed the freedom of expression.

Regional history has the magnitude to fasten the past and present. The Pakosati period lasted for thirty or forty years of his ruling was a short period of political integration. Pakosati, who ruled the region, was the contemporary of Cyrus and had close relations with the neighboring countries (Amjad, 1997). The regional governments and center had amazing relations as Pakosati requested the Massagas (government of Massagas (Chakdara) a political region) to assault the Cyrus army while the Massaga remained a sovereign region or the political unit of Gandhara (Rashid, 1992). In those days Massaga (Chakdara and Swat Barikot) were ruled by Thomyrus (Queen) while her son the (Commander in Chief) withstood Cyrus Army (Amjad, 1997). He (Cyrus) was killed in that battle but his army succeeded. However, Chiragh (2001), declares Gandhara is the most stable and strong Kingdom by 700 BCE included Pushkalavati (Charsadda), Sakla (Sialkot), and Taxila were the most civilized city-states and regions of its jurisdiction. Gandhara throughout its history did not lose its primacy. Its Geopolitical importance made it a passage, a battlefield, a hub of civilization and a cultural crass-road that contributed enormously to the regional political history.

\section{Achaemenids Gandhara: 550-327 BCE}

Aftermath a stable empire Gandhara came under the rule of Achaemenids. However, it did not prolonged for long time in their direct control but continued an adjacent region and tributary state of them. The Achaemenids rule in Gandhara continued aftermath Pakosati that had great implication for the region. The Persian empire was a great empire at that time and had 
influential role in the region. The founder of the Persian Empire, Cyrus the Great was interested in Gandhara in the territory abode by their Indian cousin while they called Gandhara 'Paruparaesanna' meant beyond the mountain region (Olmstead, 1948). Cyrus had great and well-organized army to enforce authority regardless the ethno-cultural diversity in the Empire. $\mathrm{He}$ (Cyrus the Great) established the Achaemenids empire in Persia being a great leader of the world (Frye, n.d). Darius I period is recorded from 522-486 BCE while Achaemenid Empire during that period reached enormous size under his leadership

He had a great empire while for political administration, there were many capitals as Ecbatana (modern Hamadan) and Pasargadae in Persia as well as Babylon as the winter capital. Not only at present but in the ancient past the clash of civilization lingered a dominant discourse. Persian and Greek had remained the great power of ancient times, though during the rise of Achaemenids the Greeks had been a prosaic issue for them (Olmstead, 1948). Achaemenids Empire had influential role in the region being adopted the policy of divide and rule on the part of their expansionism. Naveed (2015), claims, that Gandhara was introduced from the Achaemenids kingdom during Cyrus the Great rule (558-538 BCE). Robb (2002) also views the movement of people, armies, and their mutual influences of eastern and western civilizations that recorded from the historical Achaemenids period (530 BCE). It was the period of its rise in the region. Though Gandhara dates back to earlier period by 600 BCE as, urbanization (city culture) and economic prosperity could be seen the blessing of regional development (Avari, 2007).

Throughout the Persian times, Gandhara existed a political region called satrapy (province) while satrapy was ruled by Satrap (Governor) the protector of the kingdom or the region (Olmstead, 1948). The Persians introduced the centralized system of administration and bureaucratic structure in region. Gandhara went in their subjugation but the region did not remain in their direct control however persisted a tributary state of the Achaemenids kingdom, known as satrapy (Naveed, 2015). The Satrap (governor) of the province who ruled the region, had ministers and a miniature court. He includes that, the governor of the province, on one hand, carried out the civil administration while on the other was the head of levies force of concerned satrapy (Olmstead, 1948). Cyrus ruled for three decade until 530 BCE when he died in a battle in Massaga (Gandhara). The head of region (Satrap) that oversaw a territory while governance embedded in the loyalty and obedience of concerned regional head.

Why Achaemenids interested in the region? It had geopolitical importance as well had bettter economic condition that means Gandhara had been developed prior to the rule of Persian. Mark (2012) claims that urbanization and wealth were the main factors which compelled Cyrus the Great to expand the Persian rule to the region. The expansion further continued and during Darius I (the son of Cyrus the Great) Gandhara region completely went under the mastery of Persian law in the next 10 years. During the king Pushkarsakti the internal disintegration could be recorded which paved the way for King Darius to subdue the region and he ultimately succeeded to establish his rule in the region. According to Higham (2003), Gandhara remained their 20th province which later came under Alexander's rule during Darius III. The earlier parts of the Persian Empire were comprised of, Gandhara region, Sind, (Indus), Baluchistan including Afghanistan, while the Gangetic basin was vice versa (Avari, 2007). Cyrus had been recognized a great symbol both in the term of human rights and politics, who greatly influenced both Eastern and Western Civilization. Under the Achaemenids, infrastructure had been developed which resulted on extensive trade. The economic activities boosted the political 
stability in the vast and extensive empire. According to Robb (2002), the Persian rule existed till Darius III followed by Alexander, of Macedonia, that settled in the region by the defeat of the Persians.

\section{Macedonian Gandhara: 327-316 BCE}

Alexander's invasion is considered a great breakthrough in the regional history being the splendid part of the political history of Gandhara. Greek and Gandhara relations had been recorded prior to the invasion of Alexander. Panini had been mentioned the Greek script by confirming that India (Gandhara) had relations with the Greek (Nehru, 2004). He (Alexander) was privileged in Greek being a monarch as his father Philip to protract his (father) mission (Chamoux, 2002). He initiated from Amphictyonic council as well from the league of Gorith (puppet of Greek states alliance set up by Philip) that professed paramount position. Achaemenids ruled Gandhara from 550 to $327 \mathrm{BCE}$ but Alexander did not continued for long time. Though Alexander victory is exaggerated but aftermath the invasion his (Alexander) army turned back soon to their homes (Naveed, 2015). At the earliest, Alexander united the country as a federation in $327 \mathrm{BCE}$ and then decided to lead an expedition against Persian (great Power of that time) in Asia (Chamoux, 2002).

Gandhara witnessed flow and ebb during the passage of time hence the Macedonian Gandhara had the distinguished position. Around 380 BCE the Persian hold on the Gandhara had been weakened and many small kingdoms sprang up in the entire region. In 327 BCE Alexender conquered Gandhara including the Indian parts (satrapies) of the Persian Empire. Gandhara came under the suzerainty of another power, when Alexander arrived in the region. His army laid siege of Bazira (Birkot) but failed to take the town (Rashid, 1992). The ever-first who confronted Greeks on the frontier were Assakenes, they were dwelled in the Northwest of the Indian subcontinent while Pushklavati was the headquarters of Gandhara (Avari, 2007). Alexander faced multitudinous afflictions in the Hindu-Kush belt and surrounding areas and then proceeded to Taxila where he gathered about 100,000 soldiers (Chamoux, 2002). The ruler of Taxila Raja Ambi dominated the region between the Indus and Jhelum River. Raja Ambhi supported him being a diplomatic one. As Chamoux believes, that, when Alexander arrived at Taxila he (ruler of Taxila) was involved in war with his eastern neighbor Raja Porus while he needed his (Alexander) support (Ministry of Foreign Affairs, MFA, 2016). It shows the political structure of the region. However, Naveed (2015) views that when Alexander arrived in Gandhara region he allied with the Raja Ambhi to subdue Porus that was a constant threat for Taxila and the surrounding regions. He (Alexander) stayed in Taxila shortly and then moved to the Baluchistan region.

Though the Greeks arrived the region in 327 BCE by replacing the Persians but Amjad (1997) argues that in 360 BCE, Gandhara depleted from Achaemenids rule. Sanujit (2011) endorses the independent structure of the region that, the emergence of the local kingdoms resulted in 380 BCE when the Persian lost the rule in Gandhara region. The independent position of the region seems the pertinent feature. Macmunm (1978) finds the tradition of the whole region of Gandhara comprised of sovereign kinglets. After the arrival, Alexander nominated officers as Satraps (governor) of the new provinces, and Oxyartes was appointed in Gandhara to the position of Satrap by 326 BCE. 
Though the Greeks soon lost the control of Gandhara however the Seleucid dynasty of Greek continued to exist in the region (Spain, 1963). The Hellenic Civilization left in-depth implications on the region. The term Hellenization is the contribution been coined for the spread of their culture, language, and population in the Persian Empire after the Alexander invasion (Sanujit, 2011). Alexander the Great, arrival the region after the Achaemenids which brought gross transformation in the region. In Gandhara the Greco Buddhist cultures, religion, art, dresses, statues are reflected and absorbed the Hellenic colors known Gandhara School of art (Mark, 2012). The socio-cultural implications deem the momentous contribution of the Hellenistic Civilization. During that era, the cultural transformation occurred and new discoveries had been carried out (Chamoux, 2002). Alexander eight years campaign and its implications on Gandhara were multidimensional. Alexander no longer persisted in Gandhara, however, his rule prolonged for several generations that had multifarious implications on the region.

The political fragrance of Greek could be observed in the political structure of Gandhara. The political system contributed by the Greek is the magnificent of the history. The existed and prevailing approaches associated to them were Tyranny, (rule by one) Oligarchy (rule by a selected grump) Monarchy (rule by inheritance) and the ultimate one was Democracy (rule by people, the male citizen) (Cartwright, 2018). In addition, the word democracy is taken from the Greek "Demos" means the citizen body at entirety, while Athens is declared the birthplace of a "democratic" democracy.

In $323 \mathrm{BCE}$ after the death of Alexander, the Seleucus compelled to flee from Babylon but on the support of Ptolemy made his recurrence possible till 320 BCE. He succeeded to subdue Persia, Media along with Punjab in 305 BCE (Sanujit, 2011). The reign of Seleuccus I continued from 312-281 BCE however in Gandhara they lost the rule in 316 BCE that came to an end to the fullest by 305 BCE. Greeks was defeated and replaced by the Mauryan Chandragupta (Robb, 2002). In India Greek (Yavanas) ruled much of the Northwest (Gandhara) and had been arrived at Patliputra (Patana now Behar) under Menander around 155-130 BCE Alexander left sizeable Greek populations in the region he ruled. The Macedonian Gandhara is the integral part of regional history.

\section{Mauryan Gandhara: $316-185$ BCE}

The political situation of Gandhara shifted to the indigenous and regional rulers of Indian subcontinent when the Mauryan superseded the Greek in the region. Chandragupta Maurya is believed to be the ever first emperor who included Gandhara in his great Empire (Spain, 1963). He (Chandragupta) (321-297 BCE) in 316 arrived and conquered Gandhara region. He was succeeded by Bindusara and Ashoka the great respectively. Gandhara had been a part of Persians followed by Greeks after the emperor Pakosati in the region. Chandragupta the sole lord in Punjab and Sindh against a new conqueror Seleucus Nector. He established his role in the region till 312 BCE He had been followed the Alexander's model in the region and merged Persia including the remnant Satrapies (regions) beyond the Indus in the kingdom and envisioned a large empire in the region. Chandragupta Maurya organized his army against the Seleucus Nector (Greek general) while his army was comprised of the Gandharan including adjacent regional peoples and tribes (Jawad, 2012). Seleucas was pushed back from Kabul (Paropanisade), Herat (Aria) Kandahar (Arachosia) and these regions came under the control of Chandragupta. The foreign rule came to an end and the great period of Mauryan started in 
the region. Chandragupta by $316 \mathrm{BCE}$ defeated the Macedonian general of Alexander the Great (Hayat, 2007). The Mauryan Empire established in the region in 305 BCE. Jawad (2012) admits that Chandragupta ruled over the region (besides Gandhara) on Punjab, Sindh, Kashmir, and Gujrat. He conquered Gandhara and merged Taxila in his Empire while his kingdom comprised of the Indian subcontinent as well as extended to Afghanistan (Avari, 2007). Gandhara remained the central part of Maurayn Empire for about a century and a half.

Chandragupta Maurya was the great emperor and had sophisticated administrative system of realm. He got the services of Kotlya as the adviser and chief minister. Earlier the Mauryan leadership was brought up in the cosmopolitan city of Taxila that had been passed the ever first University of the world where Kotlya remained his teacher. Jawad (2012) provides that Chandragupta Maurya was taught for seven or eight years in Taxila University where he graduated in the regional and international politics of that time. He (Chandragupta) had friendly relation with Kotlya while earlier on his (Kotya) advice fought against Seleucus (Chiragh, 2001).

The Mauryan policy of expansionism was not totally based upon the war and aggression but also included on the effective diplomacy. Chandragupta on one side fought against Greek while on other hand developed friendly relation with Seleucus I, that ultimately resulted on the signing of a peace treaty (Jawad, 2012). The daughter of Seleucus Nector was married to Mauryan after the defeat of Greek in a deal (Rajput, 2018). Mauryan Empire persisted in hierarchical order which further succeeded by Bindosara and Ashoka the great respectively (Chiragh, 2001). Chandragupta Maurya (322 to-298 BCE) ruled Gandhara (all most the northern areas) while his son Bindusara (298-272 BCE) ruled throughout the Indian subcontinent (Mark, 2012). Ashoka (Lived, 304-242 BCE) the son of Bindusara and Grandson of Chandragupta Maurya had been passed one among the great rulers who contributed enormously to the regional political history.

The Mauryan rule further extended to their family Bindosara (son of Chandragupta) while he made the appointment of his two sons the governors of Taxila and Ujjain (Jawad, 2012). Ashoka replaced Sumana aftermath his failure to cope with the upheaval at Taxila. He (Ashoka) started his career as governor of Taxila in Gandhara. The Mauryan Empire during the period of Ashoka met its apex embedded in his welfare outlook of governance. He focused on the political stability and religious harmony in the region. According to Avari (2007) the Mauryan Empire divided into provinces (unites) and districts while princes and royal families enjoyed the provincial government, including the bureaucracy that had been controlled by officers from top to bottom.

Ashoka the Great introduced social, religious reforms and a sophisticated political system though he was the exponent of tight control in the context of behavior (Robb, 2002). He propagated Buddha`s teaching and principles which are founded in rock and pillars inscriptions in the region. Ashoka believed that the power should be vested in the state for the development, socialization and sympathy including spiritual accomplishment.

Religious and secular configurations were paradoxically embedded in the political system at that time. Being a proponent of Buddhism, he (Ashoka) guaranteed the freedom of other religions in his realm. Avari (2007) also confirms that multiple religions worked freely regardless of any sort of pressure and state interference. The religion seems the key component 
of empire that had been captured strong and influential role in the political system. For the spiritual purpose Ashoka initiated a new department of Dharm-Mahamatras, that provided ambassador for foreign countries called Dutas (Jawad, 2012). Ashoka after the battle of Kalinga turned to a fervent champion of Buddhism (Rajput, 2018). He believed in the sublime doctrine of Buddhism which are depicted in plains and hills of Gandhara.

Mauryan had sophisticated economic system where slaves were employed in the new land, while the crown land was managed (auditing, etc) by the superintendent (Avari, 2007). Besides the crown property the concept of private land persisted in the region, as the land purchase, etc. The financial system was based upon the taxation, with the support of huge army, included the spread structure of bureaucracy being extended to the village level (Harman, 2002). Pindakara' (tax) was collected from the entire village (Avari, 2007). On the village level, an accountant maintained the land registration, kept the record of population, taxes and sources of revenue (Harman, 2002). Besides that, the agrarian unit was village, the fertile land of the state was leased to the landlord, to some for their life while others had taxable nature as well as on the basis of rent (Avari, 2007). Harman (2002), portrays the Mauryan economic activities included on agriculture, trade, Industry, mineral, liquor, and salt. It is believed, that, Saka, Kushans, followed the Mauryan model in the region. Avari views that agriculture flourished along with trade on external and internal level while China, Rome, and Gandhara remained great partners on the trading level.

Rise and Fall deems a permanent factor on the part of history thus Mauryan empire finally declined in the region. Rajput (2018) declares Ashoka`s death for the decadence of Maurayn Empire while Avari (2007) enumerates poor communication, autonomous status of unites (region), role of governor's in the empire are the factors which led to the decline of Mauryan empire. The emergence of Gandhara witnessed the great powers of its time that significantly contributed to the foundation of the politico-historical discourse of the region.

\section{Conclusion}

Gandhara evolved and emerged as an Empire that founded a great civilization in the Northwest of the Indian subcontinent. It emerged an indigenous empire, but its political position evolved as well its boundaries varied markedly throughout its history. The early phase of the regional political history is the admixture of Gandharan Persians, Greeks and indigenous Mauryan. Pakosati founded the ever first and stable Empire of Gandhara by 600 BCE. Persians expansion transformed Gandhara into a Satrap (province) and tributary of their Empire. During the invasion of Alexander $327 \mathrm{BCE}$, the region featured with regional kingdoms and independent regions ruled by different kings (Raja). Mauryan established a stable empires 305-180 and Gandhara remained the central hub of their activities.

Gandhara in beginning remained an empire then a province followed by regional kingdoms that had autonomous status and integral part of Mauryan Empire. Oligarchy, monarchy, and republican system practiced in Gandhara. The emergence of Gandhara Civilization was the dynamic and splendid period of the regional political history. 


\section{References}

Amjad, Y. (1997). History of Pakistan. Sang-e.Meel Publications.

Andikari, S. (2019, June 25). Ancient history lists. http://www.ancienthistorylists.com

Avari, B. (2007). India in the ancient past: A history of the Indian subcontinent from $7000 \mathrm{BCE}$ to AD 2000. Routledge. https://doi.org/10.4324/9780203088500

Bogoucki, P. (2008). Encyclopedia of ancient world. Facts on File.

Burq, S. J. (2008). The origin of Pushtoon. Elias Sons.

Cartwright, M. (2018, March 18). Ancient history encyclopedia. http://www.ancient.eu/greek.governament

Chamoux, F. (2002). Hellenistic Civilization. (M. R. Russel, Trans.). Blackwell Publishing. https://doi.org/10.1002/9780470753521

Chiragh, M. A. (2001). History of Pakistan. Sang-e-Meel Publications.

Corning, P., Hines, S., Chilcote, R., Packenham, R., \& Riggs, F. (1988). Political development and political evolution (with Commentaries). Politics and the Life Sciences, 6(2), 141-172. http://www.jstor.org/stable/4235572

Dani, A. (2007). History of Pakistan through ages. Sang-e-Meel Publications.

Durant, W. (2000). Story of civilization: Our oriental study (Vol. I). (T. Rashid, Trans.) Takhiqat Lahore.

Frye, R. (n.d.). Cyrus the Great: King of Persia. http://www.britanica.com

Harman, C. (2002). A people history of the world. http://digamo.free.fr/harman99.pdf

Hayat, A. (2017, February 17). The rise and fall of Gandhara. https.www.friday.com

Herodotus. (2005). Ancient history of the world. (Y. Jawad, Trans.).

Higham, C. (2003). Encyclopedia of Ancient Civilization. Facts on File.

Iqbal, J. (2002, September 03). Gandhara Civilization a model for peace vision. http://www.thenews.com

Jawad, A. (2012). The Gandhara education system its sources and legacy. PhD thesis, Institute of Archaeology and Social Anthropology, University of Peshawar, Paksitan.

Khan, H. (2016, January 24). Blast from the Past: New language system of Gandhara civilization discovery. http://www.tribune.com.pk

Khan, R. (2014). The reclamation of Gandhara cultural heritage: Its uses in present-day Khyber Pakhtunkhawa. Taxila Insitute of Asian Civilizations, 13, 259-272. http://citeseerx.ist.psu.edu/viewdoc/download?doi=10.1.1.663.4821\&rep=rep1\&type= $\underline{\mathrm{pdf}}$

Khaw, N. B. (2016). Study and Analysis of Brahmi and Sarada inscriptions from Gandhara: Its impacts on religious, cultural and historical landscape of the region. Doctoral dissertation, Department of Archaeology, University of Peshawar, Pakistan. http://173.208.131.244:9060/xmlui/handle/123456789/3319

Macmunm, S. G. (1978). The Romance of Indian frontier. M/S Nisa Traders.

Mahajan, V. (2016). Ancient India. Chand Publications.

Mark, J. J. (2012, November 13). Ancient India. Ancient History Encyclopedia. https://www.ancient.eu/india/

Ministry of Foreign Affairs. (2016). Ancient Pakistan. Islamabad.

Naveed, M. B. (2015, July 07). Gandhara Civilization. World History Encyclopedia. https://www.worldhistory.org/Gandhara_Civilization/

Nehru, J. L. (2004). Discoversy of India. Nadim Younas Printers.

Olmstead. (1948). History of Persian Empire. Chicago University . 
Quraishi, S. (1974). The legacy of Indus: A discovery of Paksitan. Weathrill.

Rajput, S. A. (2018). The beauty and mystery of Gandhara art. Researcher: A Research Journal of Culture and Society, $3(3), \quad 1-12$. https://www.nepjol.info/index.php/RESEARCHER/article/view/21546

Rashid, S. (1992). Rides on the wind: Travelling through Pakistan. Sang-e-Meel Publications. Robb, P. (2002). A history of India. Palgrave. https://doi.org/10.1007/978-0-230-56924-9

Sanujit. (2011, January 11). Depiction of India in ancient literature. http://ww.ancient.eu Sanujit. (2011, February 12). Cultural links between India \& Greco-Roman world. htttp.www.ancient.eu/article/208/

Spain, J. (1963). Science: Asia and the Pacific. Mouton and Co. 